日平滑筋誌 (Jap. J. Smooth Muscle Res.) 3, 81-93, 1967.

消化管自動能，特に胎生時消化管ならびに 腸壁神経除外標本における興奮伝播

\author{
德島大学医学部 第一外科教授 \\ 田北周平
THE AUTOMATISM OF THE DIGESTIVE TRACT ESPECIALLY
IN THE EARLY FETAL STAGE AND IN THE SO-CALLED "GANGLION-FREE" CAT'S INTESTINE

\author{
Shuhei TAKITA \\ Department of Surgery, School of Medicine, Tokushima University, Tokushima
}

In the digestive tract of the human embryo, it was confirmed previously that circular muscle first became demonstrable under light microscope which was then followed by the development of longitudinal muscle with intramural plexus between 6 th and 9 th week of the fetal life. The present work deals with the electron microscopic findings of the digestive tract in 10 human embryos. There was evidence to show that nerve cells, presumably those of the Auerbach's plexus and their axon structure, were demonstrated in embryos of $12 \mathrm{~mm}$ in length (6th fetal week) in the absence of discernible muscular structure. This finding is of considerable interest in the functional anatomy of the Auerbach's plexus. It was shown in microscopic cinematography that peristalsis of the fetal digestive tract initiated with the development of circular muscle. Conduction of peristalsis, however, was not directional. A divergent propagation of two peristaltic rings from a single contraction ring was demonstrated in the small intestine. One of the characteristic findings of the fetal alimentary tract was that contraction could occur anywhere along the digestive tract and peristalsis might pass in either direction. At this time of embryological development, nerve elements, particularly intramural nerves, were present in the intestinal wall of the fetus. Action potentials recorded from a cat's "nervefree" ring muscle tube showed that contractions could propagate in either isoor anti-peristaltic direction. The mode of contraction was considered to be quite similar to that of the fetal digestive tract. Practically identical result was obtained with a "nerve-free" ring muscle tube treated with tetrodotoxin. With preparations of circular and longitudinal muscle layers devoid of mucosa and submucosal structure, iso-peristaltic conduction was more dominant. Anti-peristalsis was found to disappear approximately after the 30th week of the fetal life. It is reasonable, therefore, to suppose that the Auerbach's plexus demonstrated in an early fetal stage was not actively participating in the regulation of the peristaltic direction.

\footnotetext{
序

消化管平滑筋の運動が Auerbach 神経叢（以下略し て A 神経叢）によって調節されているととは周知であ る。その筋収縮が筋原性なりや神経原性なりやの論争は Magnus ${ }^{1-4}$ ), Gunn-Underhil15), Alvarez-Mahoney ${ }^{6}$, Evans-Underhill ${ }^{7)}$ ，Tiegs $\left.{ }^{8}\right)$ らの昔より活発に反復され

てきた、筋間神経叢が消化管運動をどのような形に支配 しているかを明らかにした研究は少ない。それは神経笳 間の連絡機構か汧態学的に十分には証明されていないて とや，神経要素と筋要素を別々に離してそれぞれの機能 を観察するととが至難であるととなどに起因する．他方
} 
臨床面においては， esophageal achalasia や Hirschsprung's disease の aganglionosis が指摘され，A 神経 叢の機能脱落が病因と考えられるに至ったが, aganglionic segment そのものの中における輸送障害の実体を究 明した研究はとばしい。また Alvarez ${ }^{9)}$ は消化管内容を 下方に輸送する現象を説明するために, gradient-theory をうち立てた。すなわち腸は口側において excitability や metabolism が優位にあるがため上から下への gradient が確立されていると解し，乙れがために螨動の下

\section{(1) 胎生学的観察}

生理学的観察（西島, 西村 ${ }^{11)}$, 浜 ${ }^{12)}$ ) としては, 胎 令 5 ないし 30 週のヒトの胎児 40 例を用い，食道，小腸 あるいは大腸について，自動運動の有無，収縮の形式， 方向性などの諸問題に関して Tyrode 液中超生標本の 顕微鏡映画記録法によって観察した。

組織発生学的（西村, 浜, 久保添，日下）には研究の 初期において解剖学高島教授指導のもとに胎令 5 ないし 40 週（頭尾長 $12 \sim 350 \mathrm{~mm}$ ) の胎児 91 例を用い，食道， 胃, 小腸, 大腸の H. E. 重染色, Nissl 染色および Bielschowsky（荒木変法）染色による組織学的観察を行な った。近年では解剖学大黒教授指導のもとに頭尾長 9 な いし $18 \mathrm{~mm}$ の胎児 6 例を用い，脊髄，迷走神経および 消化管を含めて神経要素の発生経路について，H. E. 重 染色，Azan 染色および Bielschowsky（鈴木変法）染 色により追跡し，他方頭尾長 10 ないし $21 \mathrm{~mm}$ の胎児 4 例を用いて電子顕微鏡的に腸壁の神経要素の発生を追究 した。

（2）腸壁神経叢除外実験（菅野，辻村，疋田)

Prosser ${ }^{10)}$ ら記載の方法にしたがい, 約 $2.5 \sim 3.5 \mathrm{~kg}$ のネコ 60 例について小腸のほぼ中央より約 $5 \mathrm{~cm}$ の腸管 を 5 個内外採取し，腸管の縦走筋々粘膜を剥離除去する ことにより A 神経叢や Meissner 神経叢（以下略して $\mathrm{M}$ 神経叢）の本幹を除去した。かかる実験は Magnus 以来, 神経叢除去の良法と解せられ, Prosser はその原 著において ganglion-free intestine と称した。しかし 厳密には, terminal reticulum や Cajal cell が含まれ ている.われわれはこの ring-muscle tube（輪状筋管） を $37^{\circ} \mathrm{C}$ 加温 Tyrode 液中で至適值径（通常 $9 \mathrm{~mm}$ ) の ガラス棒に通し, 輪状筋に対する持続的の伸展性刺激を 与え，筋の表面には縦軸線上に直径 $100 \mu$ の $\mathrm{Ag}-\mathrm{AgCl}$ 電極を $1 \mathrm{~cm}$ ごと（一部の実験では $0.5 \mathrm{~cm}$ でと）に 4 本 垂直に立て，電極接着部のみをわずかに水面上に出し，

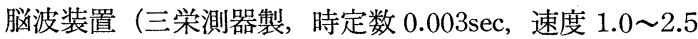
$\mathrm{cm} / \mathrm{sec}$ をを用いて，表面導出法で，ただし 不関電極は
向き伝播の方向性が生来決定されているものであると唱 えた。との学説は広く一般の支持を得てきたが，われわ れはこの理論の正否を追究するため, 解剖学教室の助力 を得て, 笳神経発生のきわめて初期における形態と機能 とを観察せんと企てた。他方では，ネコの腸を用いて Prosser $5^{10)}$ の実験を追試して堀り下げ，輸状筋の管状 標本について機能を観察し，神経叢を除外した状態に関 して興味ある結果を得たので, てれらを総合して報告 し，諸家のご批判を受けたい。

方 法
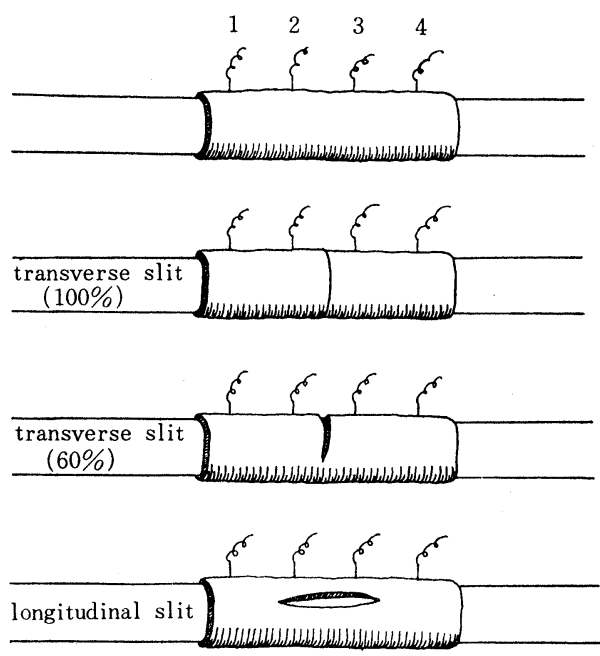

図 1. 腸管神経叢除外実験 ネコの小腸輪状筋管における興奮伝播の記録法で, ガラス棒にさした各種筋管および 4 本の導出用電極 (間隔 $1.0 \mathrm{~cm}$ ，一部において $0.5 \mathrm{~cm}$ ) を示す。

Tyrode 液中に入れ，それぞれの電極汃ら活動電位を記 録した (図 1 )。 4 本の電極 $1 \sim 4$ のうち 2 と 3 の中間に おいて tube に circular slit を入れ，その範囲を部分 的 slit (60\%) から全周 slit (100\%) までの段階に分け て興奮の伝播状態を観察した。また電極 2 から 3 にまた がる longitudinal slit を加えた場合をも追加した. tube は自発興奮を営む場合が多いので, 特殊の場合にのみ, 矩形波刺激（日本光電社製， $20 \mathrm{~V}, 500 \mathrm{msec}$ ）を加え, またはピンセットによる pinch により起てされる興奮 の伝播状態を記録し, 他方では $16 \mathrm{~mm}$ 映画により収縮 の経過を記録した．別に対照実験として，以上と同様な 実験を粘膜と粘膜下層を剝脱した 2 層筋管（すなわち 神経叢欠如管）ならびに全層健在の正常腸管についても 実施した。 


\section{(1) 胎生学的観察}

ヒトの胎生初期において 19 例の小腸の自発運動を顕 微鏡映画的に記録するに，腸壁には胎令 6〜8週におい て, 輪状筋発生とともに弱い輪状収縮論の発現をみる. との収縮輪は明らかに伝播性であって 浅蠕動の形を示 し, 胎令が進めば強い形態となる。特筆すべきととは, この収縮輪が正蠕動方向にも逆蠕動方向にも進行するて とである. 図 2 は胎令 12 週の腸壁に見られた蠕動の所 見であって，一個所で収縮輪が強いくびれとなって内を 増し， 2 個の収縮輪を形成し，正逆両方向へ進む蠕動輪 として divergent 亿伝播する（図 2, No. 2-5). 周期は, 相ついで頻発する場合は約 $7 \mathrm{sec}$ を数えるが，一般には 不定である.しばしば 2 つの収縮輪が convergent に進 み衝突する場面も見られるが，てれは相隣接した $2 つ$ の pace maker から正逆両蠕動が進発し, 途中で衰弱す るととなく伝播して来たてとを意味する。一方へ向かう 蠕動が早く衰弱すると蠕動はあたかも一方向性のでとく 見られることもあり，その方向性には定律がない，正蠕 動と逆蠕動の発現する頻度は，乙の胎児の例では，ほぼ 同数である.腸壁はどの部分でも pace makerとなりう るものであって, 多数の個所で at random に，それぞ れ無統制の収縮が反復されている.腸内容は肉眼的にも 顕微鏡的にも明瞭ならず，ただ粘膜紱賠が蠕動収縮によ って右に左に圧排されつつある所見を顕微鏡の透過光線 により認識しうるのみである。

一般に胎令が進むとともに蠕動運動は活発化し, 胎令 12 週内外で初めで少量の黄緑色腸内容を認め, 順次そ の量を増している、腸壁の発生が進んで増大し内容も増 量してくると, 自然に逆蠕動伝播が減少するが，胎令約 30 週でろまでは逆蠕動はなお消失していない。

他方, 光学顕微鏡的に腸壁構造を観察した結果を参照 するに，小腸では輪状筋の初発する $7 〜 8$ 週において運 動も初発する.との原始的収縮といえども，その形は蠕
動であって必ず 2 方向伝播性を認める.従来の光学顕微 鏡的知見によれば, 輪状筋のみが最初に出現し, A 神経 節と縦走筋の発現は約 1 週内外の遅れを示すと称せら れ，著者もまた同様に報告11-14) してきたが，電顐的に 精查すると事実は異なるととが判明した.図 3,A は頭尾 長 $12 \mathrm{~mm}$ （胎令 6 週相当）のヒトの胎児小腸上部に相当 した位相差顕微鏡所見である.白矢印は墏膜に比較的近 い腸壁において数個の細胞群が多少周囲の細胞とは形態 を異にする疑いを以て，その部分を目標にして電顕で追 究（図 $3, \mathrm{~B})$ したととを意味する。ての標本においては 筋細胞の分化は明瞭でない. 図 $3, \mathrm{~B}$ は図 $3, \mathrm{~A}$ の矢印の 部位に一致して,一群の fibroblast $(\mathrm{F})$ に取り巻かれた neuroblast $(\mathrm{Nb})$ と axon $(\mathrm{Ax})$ およびてれに随伴する Schwann cell (S) が明かに識別し得るととを示してい る.図3,Cは他の位相における強拡大で, neuroblast の 核 (Nnb)，形質中には mitochondria (Mt), Golgi complex $(\mathrm{G})$, dense body with central core (B), endoplasmic reticulum (Er), tubular structure $(\mathrm{T})$ などの 形態が散在し, 神経突起の形成も認められ，てれに接し て axon (Ax) 群の断面も見るととできる. すなわち光 学顕微鏡的に初めて輪状筋を発見する直前の胎生 6 週に おいてすでに原始的な神経細胞とその突起類をも発見す るてとができた。この事実は光顕所見における险路を償 い今までの成績を全面的に修飾するものである・すなわ ち腸壁が動き初めた時はすでに A 神経叢の細胞は原基 として存在しているてとを意味する。しかしてれのみを 以て直ちに収縮の神経原性か筋原性かを判断するととは できない。

かくのごとく, 神経細胞や突起を証明しても腸収縮の 伝播は決して下向き方向に統制されていない事実と, 発 生が進んで腸管が著しく大型に発育し $\mathrm{A}$ 神経叢の細胞 が明瞭に染色認知されるようになっても，なお蠕動伝播 のお向性は下向きに統制されていないという事実は注目

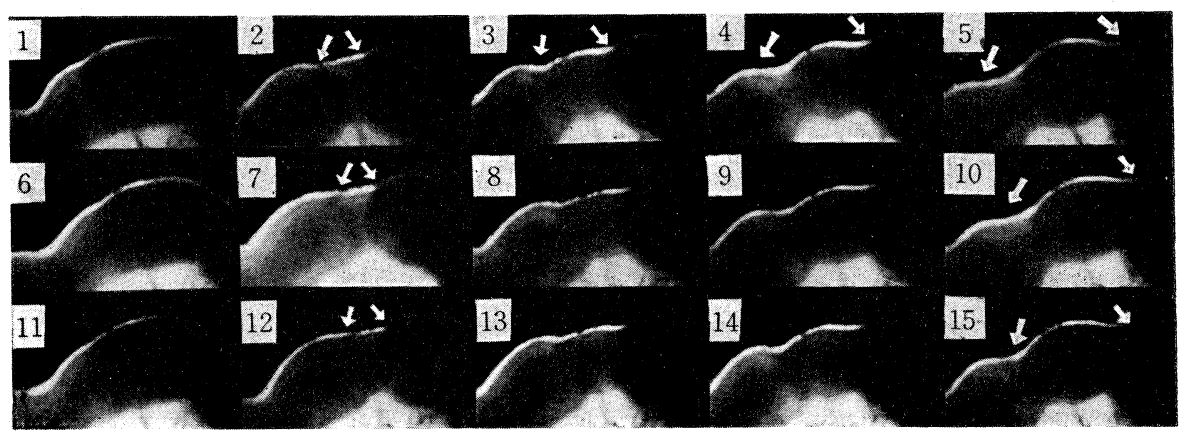

図 2。ヒトの胎令 12 週における小腸運動の顕微鏡映画所見

1 秒ごとにコマを並べたものである，矢印は一個所に始まって divergent に伝播する正逆蠕動を示す. 


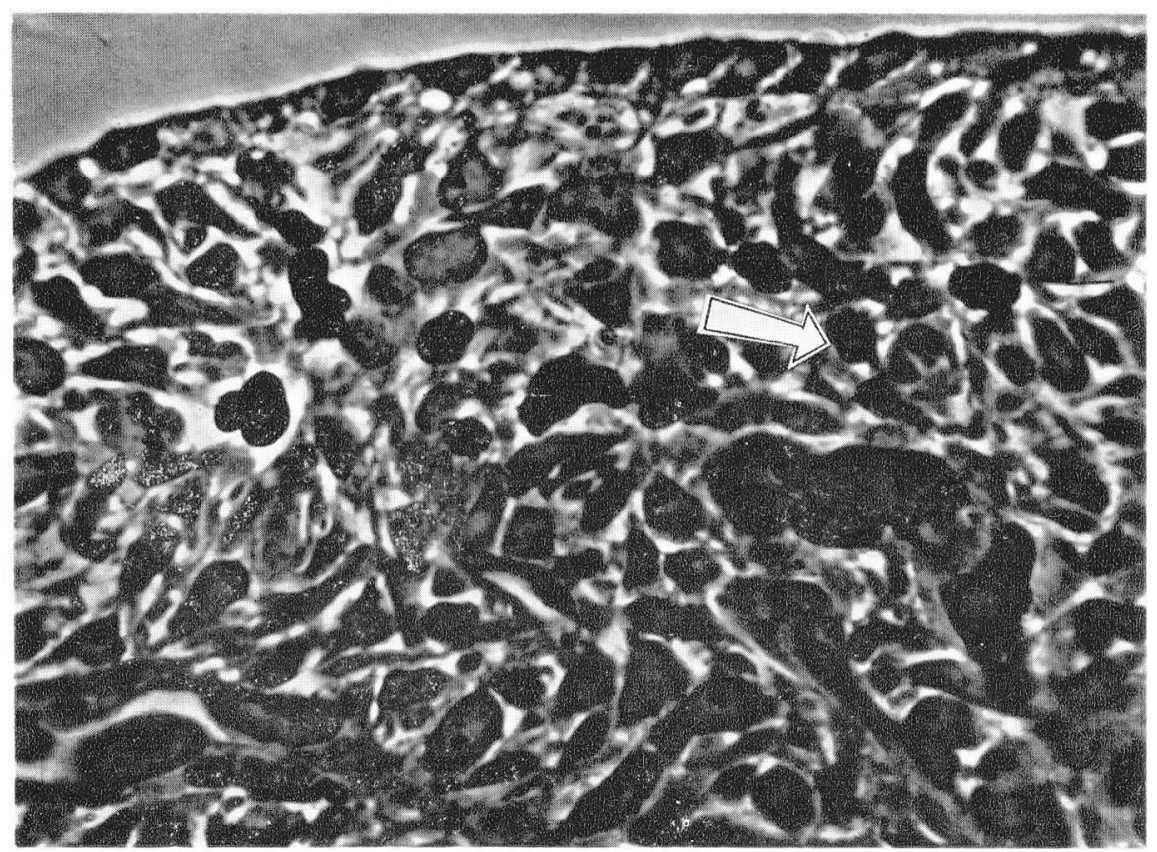

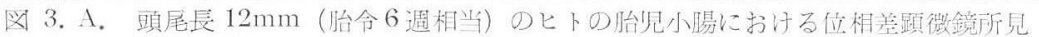

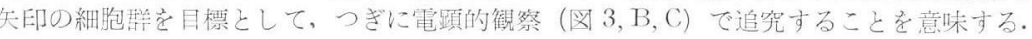

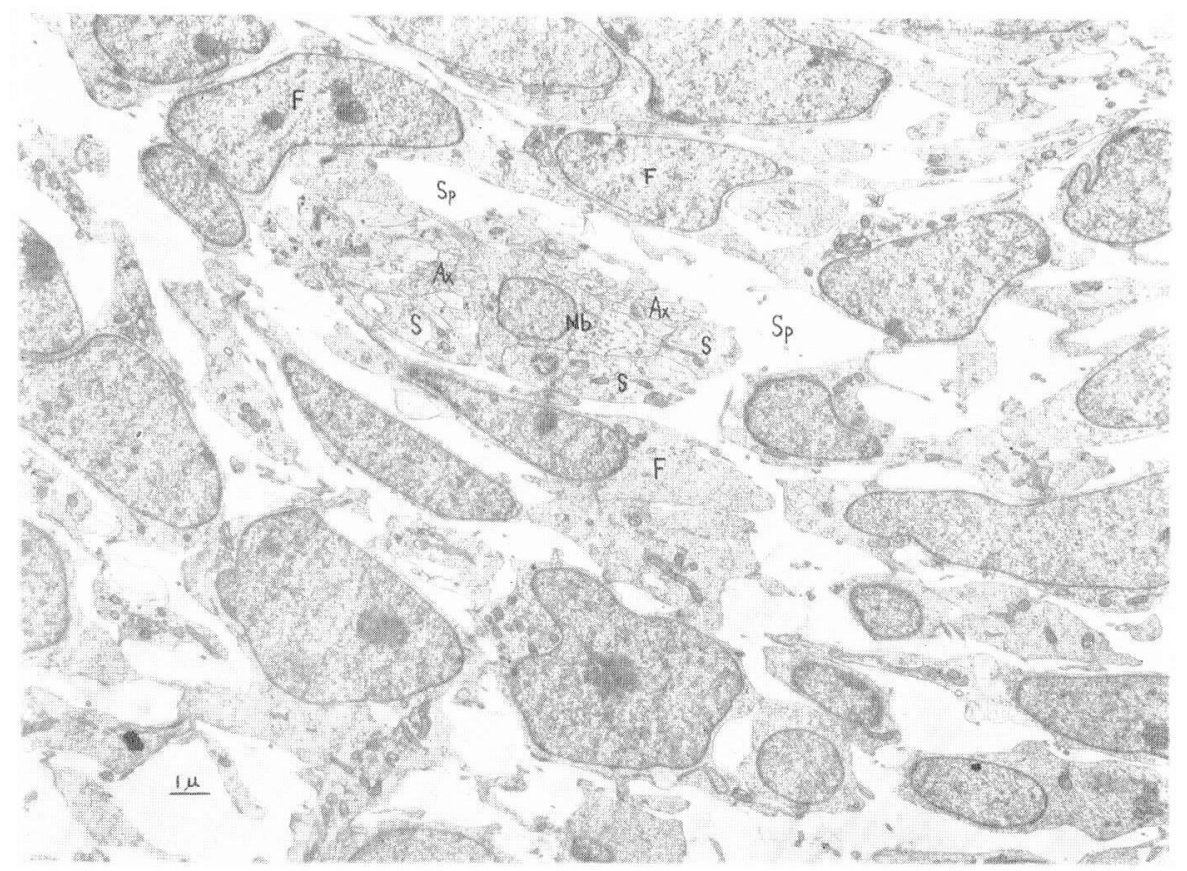

図 3. B. 図 $3 \mathrm{~A}$ と同一腸星の電子頙徽鏡所見

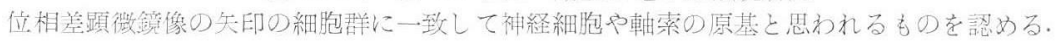
Ax: Axon
B: Dense body with central core
Er: Endoplasmic reticulum
F: Fibroblast (Mesenchymal cell)
G: Golgi complex
Mt: Mitochondria
Nb: Neuroblast
Nnb: Nucleus of neuroblast
S: Schwann cell
Sp: Subcapsular space
T: Neurotubuli (Tubular structure) 


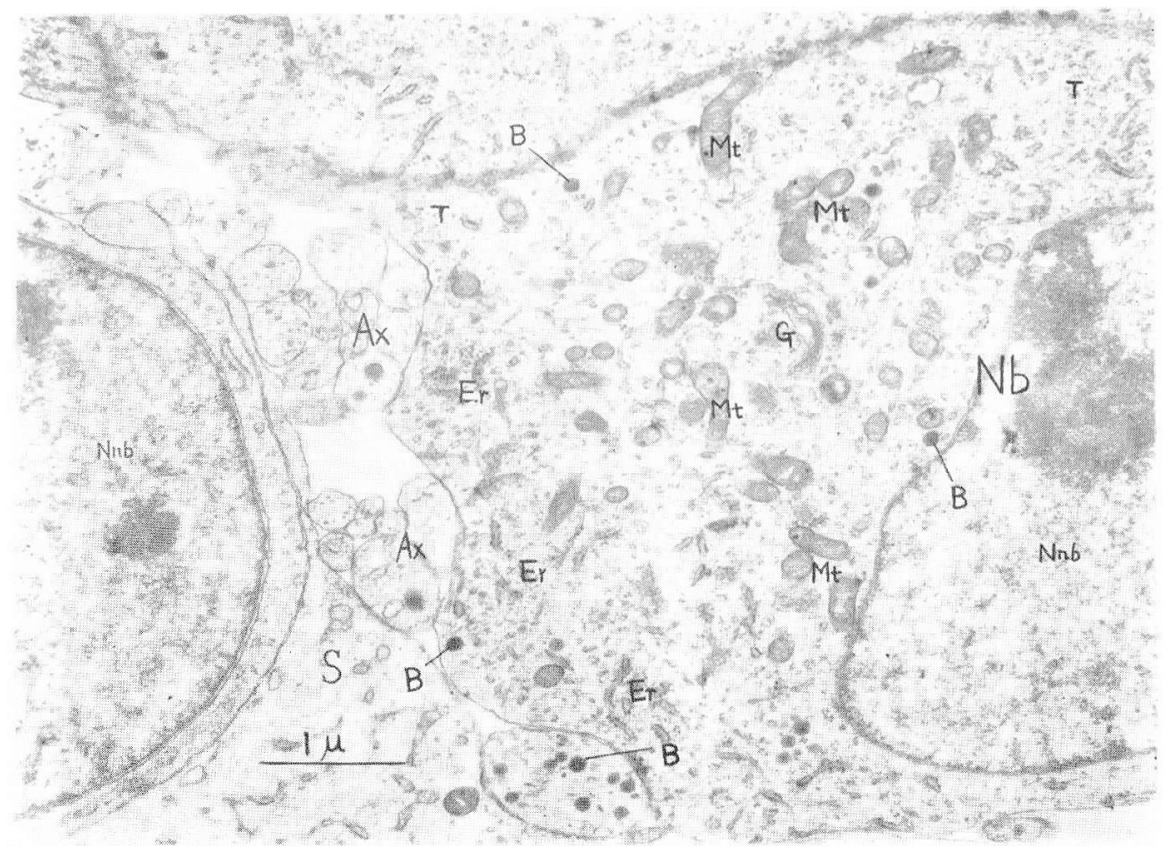

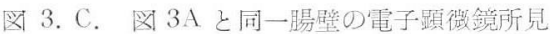
強桩大像走示す。符合は B と同様.

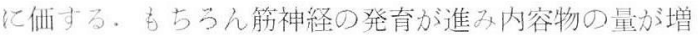
加するともに漸次逆蛙播が減じ。約 30 週内外を境子 して一応逆蝡動の姿が消失する。乙の事実上り胎生極初 期には A 神経賞はすでに発生してはいるが収縮伝播の 方向性圭調節する能力がないと解瀵される。换言すると 約 30 週以㣪になれば, 腸壁内神経細胞は筋細胞ととも 飞, 内容存正蠕動方向飞輸送する能力存獲得するに至る ものであって，筋と神経の役割り上の本質的な相違加ら 考元て，少なく子も神経細胞が逆伝播存抑制する機能を 発揮するに主ったと解するととがでるる。その他，食 道, 胃, 大腸について, 胎生極初期の顕微鏡映画的観察

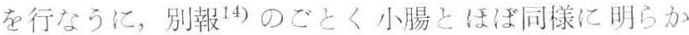
に2 方向伝播在示寸事実が証明された。

\section{(2) 腸壁神経盖除外実験}

前記の力法により作成した輸状筋管は，四４亿示すご とく，その口側端または肛門側端圭機械的に刺激すると 明ら加飞 spike burst 発生し，つぎつぎに伝播して秒 速約 $1 \mathrm{~cm}$ 内外の正蠕動あるいは逆螦動の形式がみられ る。去た自発的に司同様の蠕動加発生し, 時之して図 5 のどとく自発的に正逆両蠕動吕現われ相衝突主る所見あ り，ほば15ないし18の spike が集合した spike 群が 1 個の蠕動輪に相当し, 各 spike 群の週期すなわち蠕動
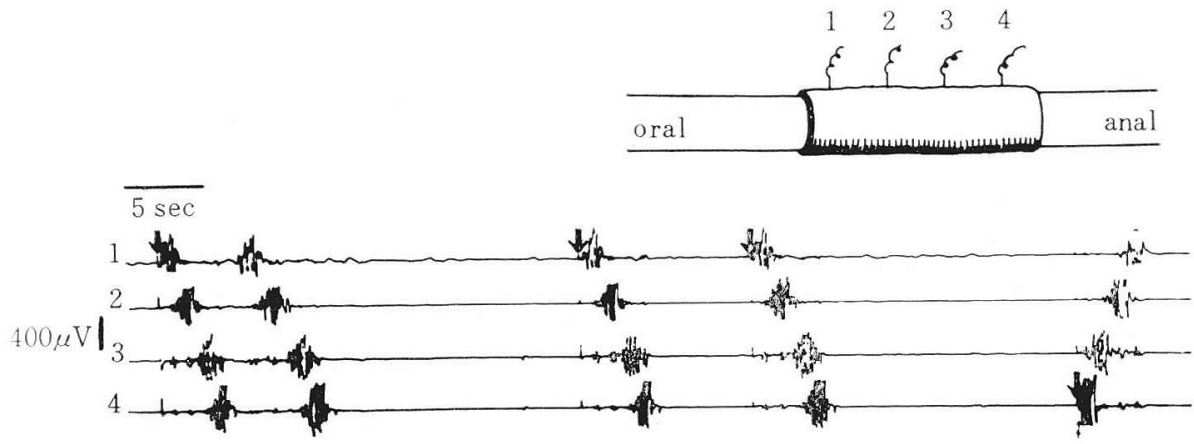

四 4.ネコの輪状筋管にお打る興奮伝播 4 曲線は $1 \mathrm{~cm}$ 間㢳にある 4 本の電極のそれぞれの番号に相当し，明らかに蠕動性伝播の形式がみら れる。機栈的刺戟 (失印) によっても, また自発的にる興奮が発生し, 正逆両方向に伝播が起こる。 


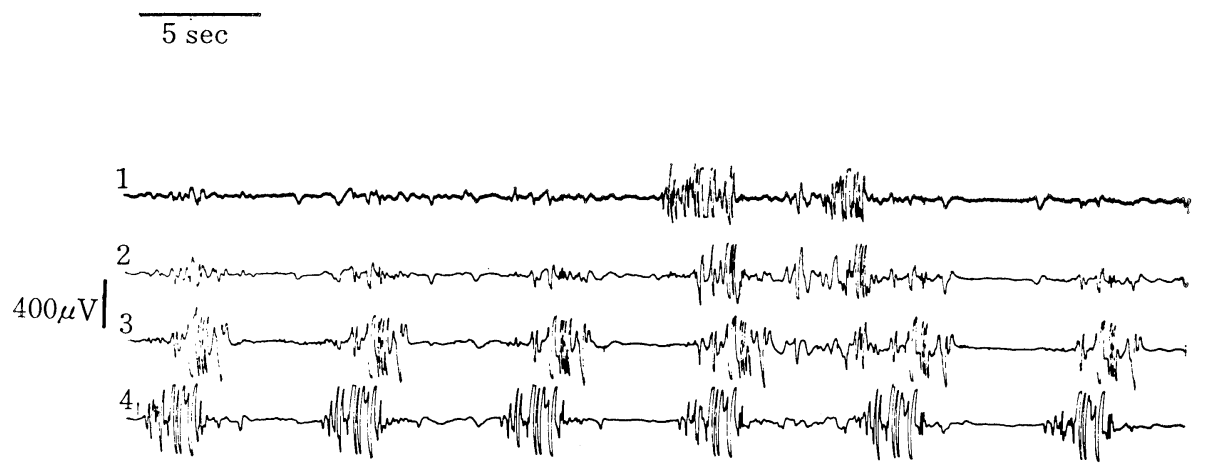

困 5.ネコの輪状筋管における興奮伝播

図 4 と同様の観察で, 自発的逆蠕動と正蠕動の衝突がみられる.

週期は $6 〜 7 \mathrm{sec}$ を示した。すすなわぢ $\mathrm{A}$ 神経叢細胞を欠 如する筋標本において明らかに蠕動は存在するが，その 伝播は 2 方向性を示し, convergent waves や divergent waves の形式を示す。図 6 はある pace maker に発生し た収縮輪が divergent waves となって上下 2 方向に伝

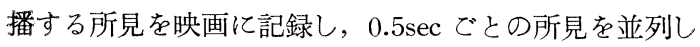
たものである.いま゙ iso-peristalsis と正逆両伝播すなわ $ち$ bi-directional conduction との 2 種について, 輪状 筋管と 2 層筋管（すなわち Meissner 神経叢除去）標本 の場合を比較したところ，輪状筋管で iso-peristalsis の 頻度は $27.2 \%$, bi-directional peristalsis は $72.7 \%$ を 示し， 2 層筋管では iso-peristalsis が 73.1\%. bi-directional peristalsis が $26.9 \%$ であった。正蠕動の伝播速 度は 2 層筋管が $2.3 \mathrm{~cm} / \mathrm{sec}$ に反して, 輪状筋管では 1.3 $\mathrm{cm} / \mathrm{sec}$ であって，はるかに遅い。

U [-輪状筋管ば $\mathrm{A}$ 神経叢細胞の本幹が除去されているた め “ganglion-free” と考えられてきたが，しかもなお terminal reticulum や神経系との密接な関係を疑われて いる Cajal cell などが残存している。そてでてれらの 影響を除外する目的で栄養液に tetrodotoxin を追加し て $5 \times 10^{-7} \mathrm{~g} / \mathrm{ml}$ の濃度となしたとてろ, 図 7 のごとく, 明瞭な蠕動性伝播の機能が維持されている.その所見は tetrodotoxin を用いない場合と同様であって正蠕動も逆 蠕動も認められる. tetrodotoxin の追加による残存神経 系の完全遮断にもかかわらず，筋が至適伸展状態におか れているならば, 蠕動の bi-directional conduction が 認められることは筋原性伝播能を否定できないととを意 味する. tetrodotoxin 投与の結果は二層筋管の場合でも ほぼ同様であった。

つぎに輪状筋管の中央すなわち電極 2 と 3 の中間点に おいて circular slit を加えて興奮伝播能を検査した。 いまその一例，円周の $60 \%$ に及ぶ slit を作った輪状筋 管では自発的蠕動あるいは誘発された蠕動は, 図 8 ので とく，正または逆の方向に一端から他端まで slit を越

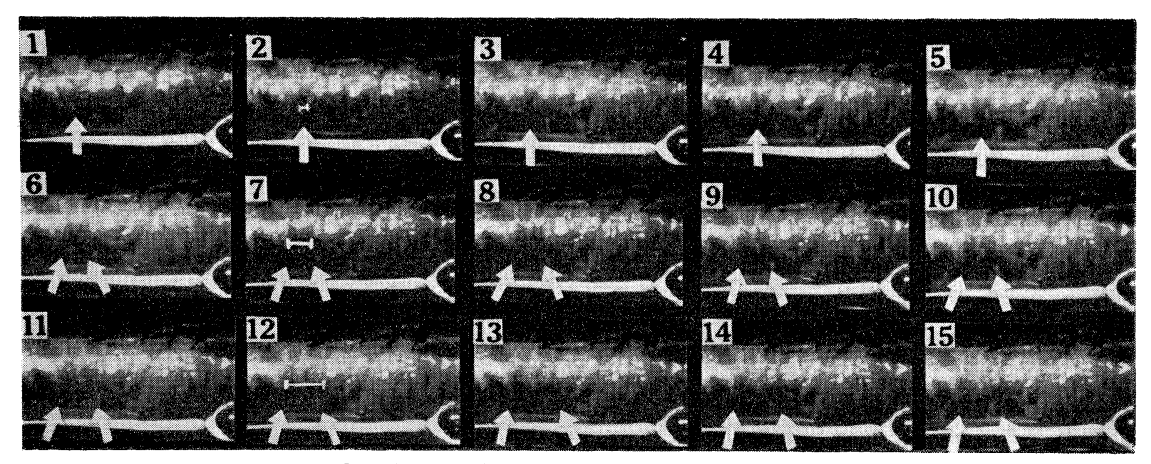

図 6。輪状筋管の収縮伝播状態を記録した映画

0.5 秒間隔のコマを並列したもので，矢印のごとく，ある pacemaker に発生した収縮輪が巾を増して 正逆 2 方向に伝播することを示している。標本の向かつて左が oral, 右が anal で, 初発収縮輪 (矢印) の位置は写真番号 1 では第 1 電極（上方より刺大）の左側にあり，写真番号 6,7 付近では収縮論左右に 拡がり右向き伝播（正蠕動方向）が電極を通過し, 写真番号 $12,13,14$ 付近では明らかに電極の右に進 んでいる. 写真 $2,7,12$ の横線は bi-directional conduction の進展状態を示すものである。 


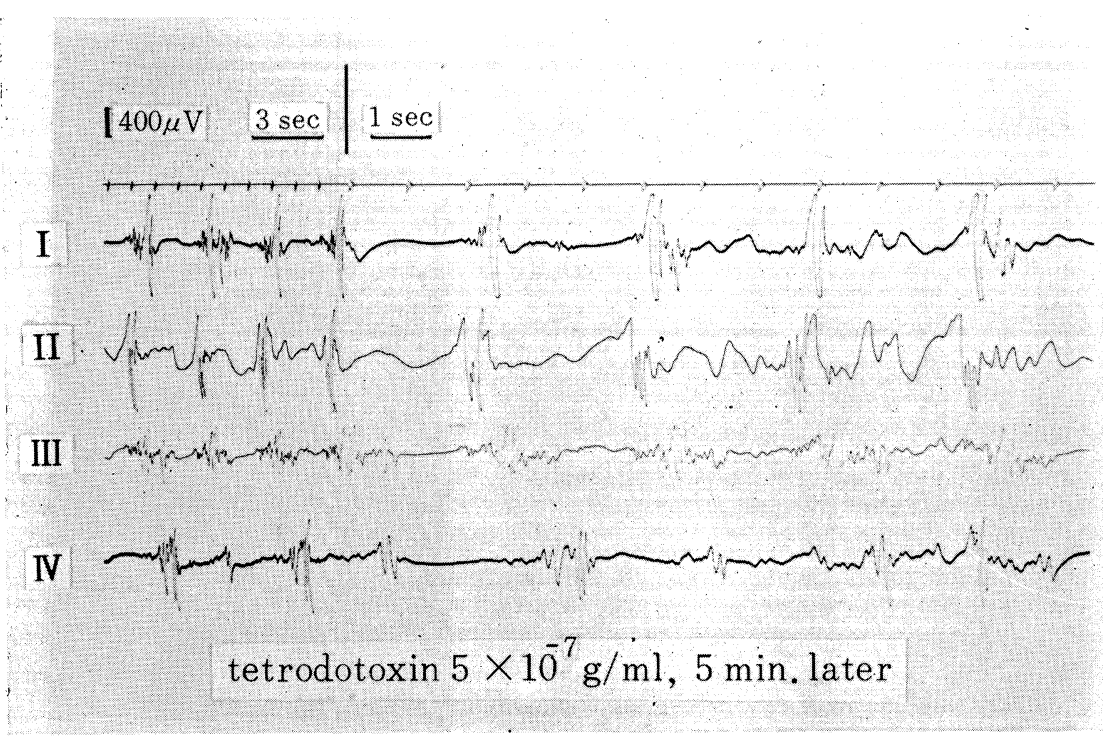

図 7. A. 輪状筋管に tetrodotoxin $5 \times 10^{-7} \mathrm{~g} / \mathrm{ml}$ を作用させ 5 分後の所見 薬剤非投与例とは著変がない.電極第 2 の部位から 2 方向伝播の蠕動か現われている.

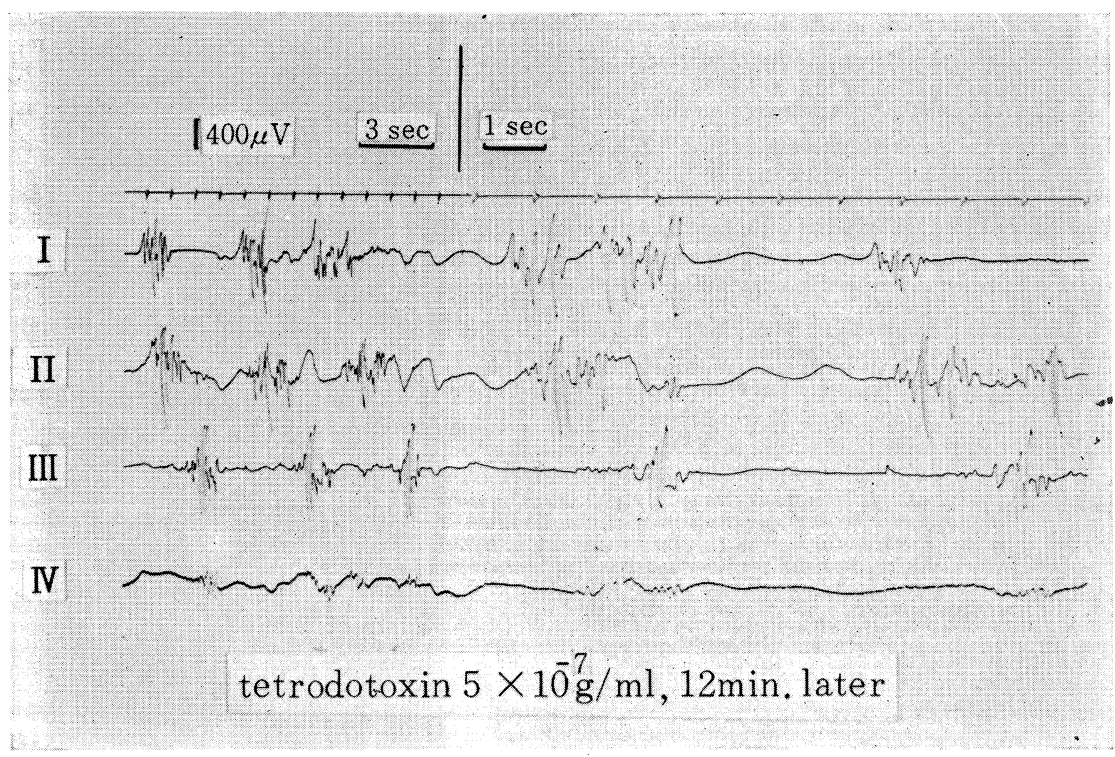

図 7.B，図7A と同一標本で, 12 分後の所見で, 著変がみられない。

えてはぼ対照と同様に伝播するととが判明した。この事 実は，縦走筋や $\mathrm{A}$ 神経叢の本幹を 欠如しても輪状筋の 連絡が一部に残っておれば筋線維の横軸方向に興奮伝播 が起とる能力があることを意味する.

さらに.Prosser ら ${ }^{10)}$ の実験を追試するために，電極 2 と 3 の中央で, $100 \%$ circular slit すなわち完全 切離の後に断端を接触させると，図 9 亿示すように，標 本の一端に加えられた刺激は最も近接した電極において spike burst の発生を誘起するが，中央の創面を越えて の蠕動性興奮伝播は絶対に見られなかった。

最後に輪状筋管に対して, 電極 2 と 3 亿またがるlongitudinal slit を作り, 興奮伝播様式を観察した。漂本 の一端を機械的に刺激すると直ちにそれに近接した電極 1（あるいは 4）において，図 10 のごとく，明瞭な spike burst 発現を認めるが，てれが正あるいは逆蠕動 として他端まで伝播する所見が見られなかった。 slit の 


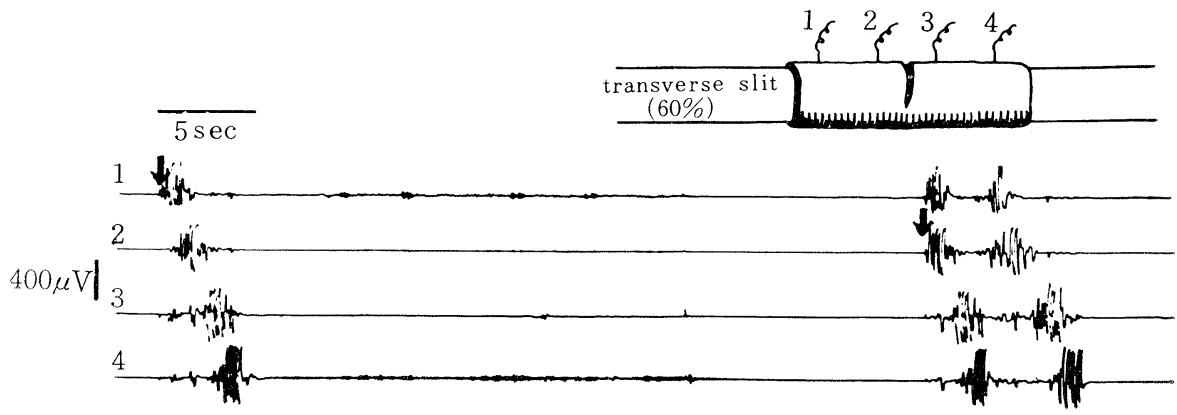

図 8。輪状筋管に $60 \%$ C circular slit を加えた場合 明らかに蠕動の形式で與奮の伝播が認められる。

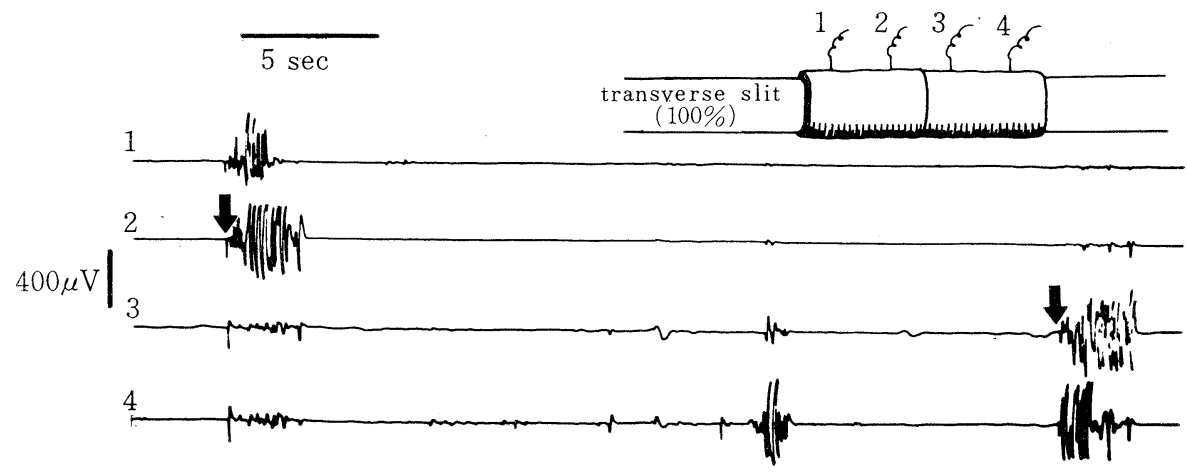

図 9. 輪状筋管の中央において完全切離後に断端を接触せしめた場合

一方に起こった興奮はその側のみの伝播は見られるが，他側への伝播は少なくとも蠕動の形式では発 現しなかつた。

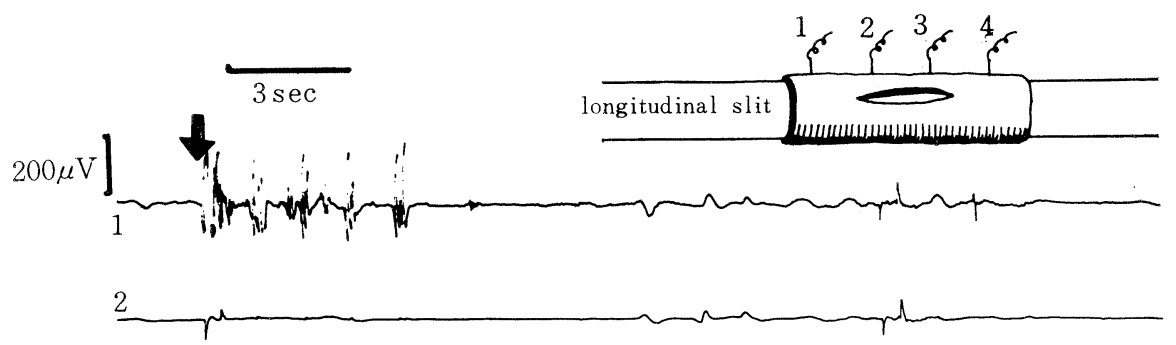

3

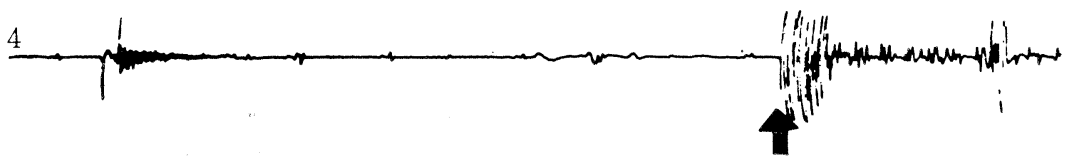

図 10。輪状筋管の中ほどに縦軸切開を加えた場合

切開区域にある電極 2 と 3 では，蠕動の伝播が block されて他端に到達しない。

ある範囲の輪状筋は stretch された状態から緩解されて いるため至適伸展刺激が除かれ，蠕動発現閾值の上昇を 招いている。したがって slit 区間は他の部とは全く環
境を異にした標本であって，自発興奮のみならず誘発さ れた興奮でもとの区間では明らかに反応態度を異にす る. 興奮伝播の起りかたは, 超生条件や刺激の程度によ 
ってまちまちであるが， slit 区間にある 2 個の電極部位 は常に同じ態度を維持し，他の stretched part に比し 興奮性低下の状態にある．少なくとも口側端あるいは肚

\section{考}

$\mathrm{A}$ 神経叢の機能については昔から興味深い研究が反復 されてきた．特に近年では，乙れを欠如する疾患の病態 生理を解明するために，ぜひ追究しなくてはならない問 題となってきた。福原 ${ }^{15)}$ は実験的局所完全貧血により 発生した腸壁神経破壊と通過障害を Hirschsprung 病の それと同類と解し，乙の segment の過緊張状態が本病 の aganglionic segment の態度に相当すると主張した。 そのような腸壁の粘膜や筋層において環境障害が永く潜 在しているはずであるから，筋が spasmophilic となる てとは当然であうう．おそらくこの段階において筋細胞 の環境障害を組織像の上から確証するととは困難である かも知れない. 著者は, ての程度の病変を Hirschsprung 病の aganglionic segment と同一視する考えかたには， いまだ到達していない. ての問題は, 本疾患の本質を解 明するため，今後に残された課題である.

そもそも Magnus ${ }^{1-4}$ は $\mathrm{A}$ 神経丵を縦走筋とともに 剥脱するととにより残された輪状筋中には神経が欠如す ると考え, 後者の非運動性が神経欠如のためであるか ら, 律動収縮は神経原性なりと解した. その後の学者 ${ }^{5}$, 6,16,17) はこれらを追試して, 該輪状筋に律動収縮の存在 を認めたので, 律動収縮の筋原性説を唱えた。福原は, これらに対し, 輪状筋標本は神経線維の終末が残存する 以上神経要素欠如とは言いがたく, 軸索の残存が acetylcholin の産生に参与するため輪状筋収縮が残存するも のであると述べ，さらに独自の方法により腸管に完全貧 血を起とさせると神経要素が除外されて運動は停止する との根拠のもとに, 律動収縮は神経原性なりと結論し た. Kuriyama ら ${ }^{18)}$ tetrodotoxin $5 \times 10^{-7} \mathrm{~g} / \mathrm{ml}$ が心 筋および横隔膜筋に対しては完全に spike を blockす るに反して taenia coli の平滑筋自発運動に対しては block するととなく，むしろ spike frequency を増すと とを認め，平滑笳における spike 発生機序は横紋筋の 場合と本質的に異なるものありと証明した。

われわれはネコの輪状筋管の組織学的検索により, 先 人のでとく神経要素を完全に欠くものとして取り扱うと とには抵抗を感じる.しかし A 神経叢の細胞体を欠く ことにより神経叢の本幹が除去されて神経系機能に著し い障害が加えられたものであると解するので，ての観察 法は A 神経叢除外実験の一種として有力な示唆を与え うるものと信じている.かくのでとき条件下においてて輪 状筋管は明らかに周期性自発興奮を示し，しかも一点の 収縮輪から正逆両蠕動が生まれて上下 2 方向に伝播す
門側端に発生した興奮は slit 区間を越えて順調に他端 まで蠕動形式で伝播するととは困難な状態である。

\section{察}

る.てのような興奮が随時随所に発現し, 所によれば両 側から収縮輪が集合的に来襲して一点に合流する。てれ らの形態が多数の個所で不定の週期で複雑に展開されて ゆく場面はあたかも心臓細動を見るの感がある. A 神経 對を完全に備えた標本（すなわち 2 層筋管）と輪状筋管 とを比較してみると, 蠕動伝播速度は 2 層筋の方が明ら かに速く, iso-peristaltic conduction と bi-directional conduction の頻度の差をみると, 二層筋の方がはるか に isoperistalsis が多い.

さらに tetrodotoxin を 2 層筋管や輪状筋管に投与し て残存神経要素を除外したとてろ, 興奮の発生や伝播の 形式など control となんら異なるとてろを発見しなかっ た。これは Kuriyama ら ${ }^{18)}$ の観察と相通ずるものがあ る.

すなわち神経要素を完全に除外したと思われる実験に おいて 2 方向伝播機能が残されている事実は動かしがた い. てれを以て消化管平滑筋運動の筋原性説を樹立する には，なおいく多の証明追加を必要とするが，従来着目 されなかった一つの有力な事実がこてに発見されたてと に間違はない.

ひるがえって先人の観察記録を考察するに，縦走筋剝 脱後の輪状筋運動を単なる収縮とのみ解して, その伝播 様式に関する精細な観察はいまだ行なわれていなかっ た. Prosser ら ${ }^{10)} は$ ganglion-free cat's intestine では spike burst の存在と slow potential の久如を認め, 刺 激による興奮は muscle spiral によって伝播が可能と 説いた。その掲載する曲線を精查するに，自発的収縮の 伝播特に bi-directional divergent propagation の機能 に関する着目がない。ての様式は緩徐な伝播であって， 多数の電極を使用し映画記録を用いて証明しうるもので あり，消化管運動の基本形式と称して過言ではない.

さらに Prosser ら 10) は横切離再接触標本において ephaptic transmission の存在を強調した。 われわれの 実験では slow potential の欠如に関しては討議しがた いが，切離再接触実験では螎動形式の transmission は 絶対に証明されなかった。

平滑筋自動能の基本的追究のためには，胎生極初期の 原始的運動の解明や電子顕微鏡による組織発生の観察な ど多方面の考察が必要である，ヒトの胎児特に初期にお ける光学顕微鏡観察によれば，消化管平滑筋の発生は， 直腸は別として，上部ほど早期に進む・多少の変動ばあ るが，6〜8 週において輪状筋発生とともに収縮運動が 
証明された。しかもその様式は明らかに bi-directional conduction を示し，特に小腸においては一点に始まる 収縮輪が巾を増して 2 つに分かれ正蠕動と逆蠕動となっ て divergent に伝播し，他の部位では 2 つの収縮輪が convergent に集合し衝突する場面があり，との所見が 腸壁のいたるととろに不規則に発生し，それぞれの態度 間にはなんらの連絡もなく全体的統一がない，ての所見 は前述の輪状筋管の所見と酷似する.

われわれは研究の順序として，既報11-14) のごとく， 光学顕微鏡的観察を行ない, 最初に輪状筋を確認した胎 令は食道，胃では 6 週，小腸 8 週，大腸 8 週で，縦走筋 は食道 11 週, 胃 12 週, 小腸 10 週, 大腸 13 週, A 神経 叢細胞は食道 9 週, 胃 11 週, 小腸 10 週, 大腸 9 週であ った・それらの報告は染色の技術や胎令判定の困難性, 摘出操作にもとづく胎児の破壊などのため，筋神経発生 の時点を確認するに不十分のそしりを免がれない. そこ で本研究ではさらに壁内壁外両神経の発生を極初期から 堀り下げて電顕ならびに光顕的に観察するとととした。 頭尾長 $16 \mathrm{~mm}$ （胎令 7 週相当）では脊髄より伸長した神 経線維が腸間膜の方向に進入するかたわら，上部消化管 では迷走神経が外側より進入するので, 腸壁にはきわめ て早期から外来神経の線維が存在するととは明白であ る. $\mathrm{A}$ 神経叢における神経細胞がいかにして筋間に発生 するかという問題については現在までの発生学では解明 されていない.しかしわれわれの電顕的観察では, 頭尾 長 $12 \mathrm{~mm}$ の腸管においては，筋細胞の発生が明らかで ないにもかかわらず，すでに神経細胞の原基が発現し， Schwann 細胞に取りまかれた neuroblast やとれに付随 する axon の存在を認めている ${ }^{19)}$. ての所見は腸管が動 きはじめる前から外来神経はもちろん $\mathrm{A}$ 神経細胞の原 基が発見されたととになる．ての筋間細胞の由来を論ず るに足る根拠はまだ不十分であるから本論文には触れな いが，現段階では神経細胞原基がどのような機能を持つ かを考察するととに意義がある。

光学顕微鏡的に嗜銀性を発揮するはずの神経細胞が従 来てのような初期に認識されなかったととは細胞自体の 機能がまだ不十分であったものであろうと想像される。 動きはじめた時期には，すでに神経線維も細胞も存在す るという新事実が判明したからには，あたかも平滑筋運 動の神経原性説を裹付けるかのでとく解せられるかも知 れないが，輪状筋管の神経遮断実験や tetrodotoxin 作 用の観察がこれを否定する.輪状筋のみの標本において 神経を遮断しても筋線維相互間において興奮伝播が起と り得るととは解剖学的に裏付けることが可能である. 筋 層は古くより 正確な輪状走行でなく spiral に配列され ていると言われ，広岡20)はてれを否定し網目状と唱え， 吉井ら ${ }^{21)}$ はさらにヒトの腸で硝酸浸漬法の 観察により spiral 走行を主体となすととを述べた。さらに縦走筋が これに加われば輪状筋間同志の連絡もより一そう効果的 になるととは当然の理である. また個々の筋細胞間には 微細な結合があると考えられてきた22). 特に nexus す なわち細胞間の融合は笳細胞間の興奮伝播の可能性を肯 定するものである23).

そもそも筋間神経細胞は筋の機能に対してなんらかの 制約を加える立場にある. 平滑笳の 2 方向伝播という基 本的機能を強化あるいは抑制するととが神経系の使命で あると考えて支障はない. しかるに胎生初期では, 神経 系の存在にもかかわらず，長期にわたり蠕動の方向性が 確立していない. 30 週前後より逆伝播が姿を消し, 筋 神経の急速な増大とともに蠕動の下方向き伝播性が確立 されてくる. ての順次的な機能改変は神経機能が同じテ ンポで発育したためと解するてとができる。逆にそれ以 前の神経は末熟であって方向性を調節する能力がないと 考えざるを得ない。

Alvarez $\left.{ }^{9}\right)$ は腸には gradient があるために下向き伝 播の polarity が天性具備されていると唱えたが, 著者 の胎児における事実は gradient-theory を適用するとと は不可能である.しからばなにゆえに胎令が進むととも に蠕動が下向きに統制されるかという疑問が当面解決す べき最後の関門となる.さような機能は神経の能力に帰 すべきものと説明するととは, 神がかり理論のそしりを 免がれない.

次に客観的に事実を列挙して当面の問題に考察を加え たい.

ヒトの胎児は 8〜11 週でろよりすでに羊水嚥下動作を 営むととが証明されている24-26). われわれの観察では, 腸の上部において胆汁の初めを思わしぬる暗色の内容を 発見する時期は約 12 週内外である. 腸内諸酵素の発現 は13 週ごろより証明され27,28)，腸上皮や腸腺の著しい 増殖 ${ }^{29)}$ は 6 ～週より見られ，その増殖による腸壁筋の 伸展は小腸上部に著明で, 十二指腸が最も強く, 腸液の 増量と相まって固有筋細胞に加えられる内圧は腸の上部 において高いはずである．脱落した粘膜や腸内分泌物な ぞ液状内容物は腸壁筋の反応性収縮により圧排される. 強く分化発育しつつある幽門括約笳により上を遮断され ている関係上，幽門筋収縮相では必然的に腸内容は下方 に流れる. 腸内容の存在部位については, 12〜14 週の間 に上部腸管内に認められるが，15〜16 週では回腸まで および，30 週以後ではすでに大腸に移動している. 要 するに内容はきわめて緩除に下方へと圧送されつつある と考えたい:

食道内では噮下動作が起てる以上, 強力な内圧上昇と ともに，内容は食道から胃内に押し下げられる．胃中で は強大な胃壁筋収縮により攪拌され，上下に圧排される 
が，食道収縮と幽門弛緩わよび十二指腸起始部弛緩の 3 現象が一致した瞬間, 当然胃内容は水力学的または胃収 縮にもとづいて腸の中に強く圧迫排出される。もちろん 逆方向圧排の場面も存在しうる. 一般的に言って, 消化 管上部が内圧が高い関係にあると解してよいから, 個々 の腸収縮輪が 2 方向伝播を営むにあたり, 逆蠕動伝播は 常に強い抵抗に直面し, はなはだしい場合は蠕動輪の進 行停止あるいは伝播途中で消滅を招く.

かような伝播能の衰弱や消滅の現象は腸閉塞作成実験 により証明するととが可能である．てのような局所環境 の変化は消化管のいたるとてろで存在し進展し, 発生分 化が進むと, 消化管の急速な堌大, 収縮運動力の強化が 招かれ, 消化管内容の増量と相まって, 蠕動の逆方向伝 播はますます抵抗を増すに反して正蠕動方向への伝播は 容易となる。

腸の最下端では括約の発生に基づいて，大腸や直腸に は内容停滞という上部とは異なる環境にあり, したがっ て蠕動伝播機能の改変あるいは分化がてれに順応するも のであるてとは当然である.とのような消化管の条件が 30 週の長きにわたって続くかたわら，筋神経は分化増 殖する. 特に筋機能か環境に順応しつつ発達し, これに 呼応しつつ A 神経叢では調節的な機能を獲得するよう になるととと想像される. 逆に環境に反抗するような最 高中枢様の機能を獲得するものとは考えがたい.すなわ ち逆伝播能が長期のうち消失する事実は環境にしたがっ た自然現象の傾向というべきであって，いわゆる conditioning が大きな役割りを持つ.しかし A 神経灇が発 達したから逆伝播が抑制されたと考えるには，まだ形態 学的な証明が十分でない.今後筋細胞と神経要素との間 の関係特に synaptic vesicle の態度などを電顕的に究明 するてとができるならば，その期待は大きい.

以上を要するに，消化管平滑筋の原始的運動はその発 現と同時にすでに bi-directional peristalsis の形式を示 しているものであって，腸壁の外来神経はもちろん $\mathrm{A}$ 神経叢の細胞体さえも原基がすでに発生しているもので ある・しかしその神経はまだ bi-directional conductivity

\section{結}

1. 従来, 光学顕微鏡的観察によれば, 胎生 6〜9 週 におけるヒトの胎児消化管では，まず最初に輪状筋が発 生し，てれに次いで笳間神経叢と縦走筋が発現すると報 告され，著者もてれを追試して同様の結果を以前に報 告 ${ }^{13)}$ した. 今回さらにヒトの胎児 10 例について電子顕 微鏡ならびに光学顕微鏡を併用し, 次の新しい結果を得 た.

頭尾長 $12 \mathrm{~mm}$ （胎令 6 週相当）の小腸について精查す
を iso-peristaltic conductivity に変化させる能力はない. 生下時のすでに完成された消化管では，神経の作用は興 奮伝播の強さや方向性を壁内性単独あるいは外来神経と の関連下において調節する能力があるものと考えられ る.したがって成人の消化管といえども潜在的には bidirectional conductivity の能力があるのであるから, 病態時や超生実験時に局所刺激の異常化にもとづいて, まれに逆蠕動が発現するととは理解できる.

Hirschsprung 病における aganglionic segment が内

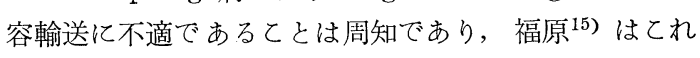
を異常緊張上昇として解釈している．その他にての segment 自身の機能に関する研究はとぼしい，神経細胞を 欠如する筋管の運動は方向性が確立していないという事 実は輸送効果を示さないととを意味するものであるが， われわれの観察結果をそのまま本疾患滴用することは 遠慮したい.しかし A 神経叢の本幹を実験的に除きさ らに tetrodotoxin により神経除去を徹底化させた場合 の機能 pattern は少なくとも本症の局所機能を理解する ための一助とはなるものであろう．ての方面の臨床的な らびに実験的観察は今後 automaticity の本質解明と直 結する興味深い研究を展開するてとであろう.

2 分された輪状筋管を単に相接触させるだけで ephaptic transmission が起しるという Prosser ら ${ }^{10)}$ の学説 は消化管吻合に親しむ外科医に夢を与えた。われわれは 同様の実験を追試して，さらに精しく観察したとてろ， peristaltic transmission の発見は不可能であった。しか し吻合線の conduction block を起とす原因すなわち組 織障害を最小限にとどめて吻合するととに成功するなら ば，術後機能回復が早いであろうという，当然の理論を 改めて認識させるものである.

輪状筋管の部分的横軸切開が conduction block を示 さない事実は臨床的の意義が大きい. てれに対して, 縦 軸切開の slit 区域輪状筋は至適伸展刺激から緩解され て興奮性の低下を招き, slit 区間の伝播障害が起てり得 るという事実は側側吻合の欠点すなわち吻合区域の拡張 弛緩を明快に説明するものである.

\section{論}

るに，筋細胞の形態がいまだ発見されない極初期である にもかかわらず，A 神経誴の細胞体と思われる神経細胞 の原基やこれに伴なう軸索の存在を認めた。この所見は A 神経叢の機能を論ずるにあたり，見逃がしてならない 事実である.

2. ヒトの胎生初期における消化管運動を顕微鏡映画 記録法によって観察すると, 輪状筋細胞の発生とともに 輪状収縮が認められ，乙の収縮は bi-directional conduc- 
tion を示すとてろの peristalsis に相当する．との原始 的 peristalsis は食道加ら大腸に至るまで，その様式に 多少の相違はあるが，いずれも 2 方向であるととが特長 であり，特に小腸ではある個所に発生した興奮から divergent propagation がみられた。これらの収縮輪は随 時随所に発生して統一性がなく, 蠕動方向性が確立され ていない. ての時期においてすでに神経要素特に筋間神 経丵は電子顕微鏡的にも光学顕微鏡的にも証明されてい る.

3. ネコの小腸管を用いて, Prosser ら 10) の実験方 法を modify し， 粘膜・粘膜下層を除去した 2 層筋管 と, さらに縦走筋ならびに $\mathrm{A}$ 神経叢を剝脱した輪状筋 管の両種の標本について, 活動電位の面より興奮伝播の 状態を解察した。ささらに部の例において tetrodotoxin $\left(5 \times 10^{-7} \mathrm{~g} / \mathrm{ml}\right)$ を作用せしめ残存神経要素の影響を除去 して観察した。その結果, $\mathrm{A}$ 神経灇の本幹を除去した輪 状筋標本ならびにさらに tetrodotoxin を作用させた標 本においては，明らかに自発的収縮が認められ，しかも bi-directional peristaltic conduction を営み, 一点には じる正逆両蠕動が標本のいたるとてろに発現し, 統一 した方向性が見られない. その所見は前記の胎生極初期

\section{文}

1) Magnus, R.: Versuche am überlebenden Dünndarm von Säugetieren. Pflügers Arch. ges. Physiol., 102, 123-151, 1904

2) Magnus, R.: Die Beziehungen des Darmnervensystems zur automatischen Darmbewegung. Pflügers Arch. ges. Physiol., 102, 349-363, 1904

3) Magnus, R.: Die Erregungsleitung. Pflügers Arch. ges. Physiol., 103, 515-524, 1904

4) Magnus, R.: Rhythmizität und refraktäre Periode. Pflügers Arch.ges. Physiol., 103, 525-540, 1904

5) Gunn, J.A. \& Underhill, S.W.F.: Experiments on the surviving mammalian intestine. Quart. J. exp. Physiol., 8, 275-296, 1914

6) Alvarez, W.C. \& Mahoney, L.J.: The myogenic nature of the rhythmic contractions of the intestine. Am. J. Physiol., 59, 421-430, 1912

7) Evans, C.L. \& Underhill, S.W.F.: Studies on the physiology of plain muscle. J. Physiol., 18, 1-14, 1923

8) Tiegs, O.W.: Studies on plain muscle. Austral. J. Exper. Biol. \& Med. Sc., 1, 131-
における小腸の興奮伝播状態に酷似する． 2 層筋管標本 では輪状筋管よりも正蠕動の発現がはるかに多く認めら れた。

4. 胎令約 30 週でろまでは逆蠕動が明らかに発見さ れ、それ以後は漸次見られなくなる.すなわち, 胎生初期 においてはA神経叢の形態は存在していても機能がない か未熟であると解せざるを得ない，胎生初期における消 化管の発育増大が口側において著明であるとと，消化管 内液の分泌や粘膜層自身の増殖の程度が上部腸管におい て高度であり, 強力な噍下動作と胃収縮などを考慮する と, 消化管内圧特に小腸内圧に関しては口側においてよ り高く，したがって内容の自然流動という現象のみを取 りあげて推論すれば，液の流れは上から下への方向性が 存在する．とのような環境の変化は胎生発生が進んで増 大の度が加わるほど顕著になるものと想像される．なに ゆえに胎生後期になって逆蠕動が消失するかという理由 は, 発育増大と環境の変化という conditioning に基づ いて，筋神経の順応が起てるというととが一つの理由に なると思われる. 今後の A 神経蕞における微細構造の 研究が問題解決の鍵となるととであろう.

\section{献}

$150, \quad 1924$

9) Alvarez, W.C.: The mechanics of the digestive tract. 2. ed., Paul B. Hoeber, Inc., 1927

10) Prosser, C.L. \& N. Sperelakis: Transmission in ganglion-free circular muscle from the cat intestine. Am. J. Physiol., 187, 536-545, 1956

11）西村菬介：腸蠕動の方向性に関する研究，日 本生理誌, 20, 143-162, 1958

12）浜 昭典：消化管自動能に関する研究，四国 医学誌，16, 620-641，1960

13) Takita, S.: On the direction of the peristaltic conduction of the intestine. Jap. J. Physiol., 7, 286-296, 1957

14) Takita, S.: Über den Ursprung der Peristaltik im Frühstadium des menschlichen Fetus. Pflügers Arch. ges. Physiol., 279, 26-35, 1964

15）福原 武： 壁内神経細胞による胃腸運動調節 の機序，日平滑筋誌，3，1-18，1967

16) Gasser, H.S.: Plexus-free preparations of the small intestine. A study of their rhythmicity and of their response to drugs. J. Pharmacol. Exp. Ther., 27, 395-410, 1926 
17) Evans, D.H.L. \& Schild, H.O.: The reactions of plexus-free circular muscle of cat jejunum to drugs. J. Physiol., 119, 376$399, \quad 1953$

18) Kuriyama, H., Osa, T. \& Toida, N.: Effect of tetrodotoxin on smooth muscle cells of the guinea-pig taenia coli. Brit. J. Pharmacol. Chemother., 27, 366-376, 1966

19) Kubozoe, T., Daikoku, Sh. \& Takita, S.: Primordial Auerbach's plexus in the 12 $\mathrm{mm}$. length human embryonal intestine revealed in the electron microscopy. J. Neuro-visceral Relations, in press

20) 広岡 治： 人及び 2,3 哺乳類小腸の組織構築 的研究, 医学研究, 12, 2935-2979, 1938

21) 吉井 勇, 西尾騰五：腸管筋層の構造につい て, 第9 回日本平滑筋学会総会 (京都)，1967 (会)

22) Stöhr, Ph., Jr.: Lehrb. d. Histologie u. d. mikroskopischen Anatomie d. Menschen, S. 112, Springer, Berlin, Göttingen $u$. Heidelberg, 1951
23) Dewy, M. M. \& Barr, L. : A study of the structure and distribution of the nexus. J. Cell Biol., 23, 553-585, 1964.

24) Szendi, B. : Arch. Gyn., 170, 205, 1940, (11) より引用.

25）藤田 茂, 春名完二：人胎児生理の研究, 人胎 児羊水嚥下運動のX線的研究，日本婦人雑誌，3， $361 ， 1951 ，(11)$ より引用

26) 松尾竜雄 : 人胎胃生理のレ線的研究, 第 1 編, 人胎児子宮内曖下運動のレ線的研究, 付, 胎児消 化管の形態的牧徴の 2,3. 名古屋医誌, 55, 269332, 1942.

27）樀 冬雪：胎児の生理的検索（第 2 回報告）消 化管の酵素に関する研究補遺, 晹管のペプトン分 解酵素について，近幾婦人科誌，10,1162, 1927.

28) 阿部 守：人胎児並に人初生児藏器デサミダー ゼの研究，其 3, 晹管デザミダーゼに就て，近畿 婦人科誌, 13, 634-643, 1930.

29) Arey, L. B. : Developmental Anatomy, 6. ed., p. 249, W. B. Saunders Co., Philadelphia \& London, 1954. 